\title{
公営住宅における身体障害者向け住戸と一般向け住戸との 連続化に関する研究
}

その 1一規模水準および平面構成の共通性一

\begin{tabular}{|c|c|c|c|}
\hline 正会員 & 片 & 岡 & 正 \\
\hline 正会員 & 中 & 園 & 畺 \\
\hline 正会員 & 有 & 田 & 幸 \\
\hline
\end{tabular}

\section{1.はじ跑に一确究の意棃と目的一}

身体障害者向け特定目的（特目）住宅は，制度発足以 来これまで, 公営住宅のなかでは一般の世帯向け住宅と は異なるものとして位置づけられ計画されてきたといえ る。これに対し，障害者に対する考え方は，「隔離 (segregation) 加ら統合 (integration) へ, 特別扱い 加正常化（normalization)，（社会の）主流への参加 (mainstreaming) へ…11) とすすみ理解が深まっていく 方向にある。このような方向に対応していくには，見状 のように特目住宅を特別な取り扱いにするのではなく， 公営住宅のわくのなかで，一般住宅と共通する計画条件 之空間構成をベースにして，身体障害者が適応できる住 戸計画の可能性を追求していく必要がある。これはまた, 高齢化時代の公営住宅として求められる条件でもあると 考えられる。

そこで，計画条件として，一般住戸と同一の住戸規模 で共通性の高い空間構成とくに平面構成により特目住戸 が計画可能になれば，公営住宅に限ってではあるが，次 のようなことを促進できるようになる。

(1) 限られた団地の限られた住楝に特目住戸をまとめ るのではなく，多くの団地と住棟で計画できるようにな り，身体障害者が希望の居住地と住棟を選定できるよう になる。

(2) 一般住戸を改造して特目住戸にすることが可能に なり，居住者が受障したり高齢化し特目住戸化の要求が 生じたとき，それに応ずることができる。

(3) 外観が特目住戸と一般住戸とでとくに区別されな くなり，また，(1)，(2により特目住戸を一般住戸に瀜合 させることが容易になり，建築的にも居住者の構成にお いてもインテグレートされることになる。

その結果, 住居についてノーマリゼーションへ一歩前 進させることになる。

\footnotetext{
太大分大学 教授・I博

和州大学 助手・I修

大分大学 助手・工修 (昭和 61 年 12 月 10 日原稿受理)
}

本研究は，公営住宅における身体障害者向け住戸（以 下特目住戸) が，中高層の 1 階に設置されることが多い ことと，住宅規模が漸増していることを踏まえ，特目住 戸と一般世帯向け住戸（以下一般住戸）との連続した住 戸計画の可能性と限界を明らかにすることを目的とす る。そのために，同一住棟にある 1 階特目住戸と，その 直上階の一般住戸との関係に着目し，両者の平面構成の 評価および対応関係について考察し，特目住戸と一段住 戸との連続した住戸計画の参考となるプランを抽出し， それをベースにモデルプランを提示することにある。

\section{2. 磁究方法}

1) 特目住戸の供給実績のある地方自治体(都道府県, 政令指定都市およびその他の市) から広く特目住戸およ びその直上階の一般住戸平面プランを収集し，研究対象 とする。

2）上階一般住戸における住戸面積の規模動向と現在 の水準を把握し，現段階で特目住戸と連続した住戸計画 の可能性亡限界を見いだすため，特定目的公営住宅建設 促進会議案 ${ }^{2}$ (以下特目促進会議案）の住戸面積につい て, 最低水準值との比較考察を行う。

3）特目住戸と一般住戸との関係を探るために，両者 の平面プランを䫛型化し，平面構成の対応および評価に ついて考察する。そして, 平面構成の関連性が強く, し かも評価の高いものをモデルプランのベースとして抽出 し, 面積の検討も行う。その結果, 特目住戸と一般住戸 の連続化のためのモデルプランのベースを提示する。

\section{3. 調盆縕要}

1) 調㚗対象

調査対象は，過去の調冝・研究および建設省の資料を もとに ${ }^{3)}$ ，特目住戸の供給実績のある都道府県および市 123 のうち 107 から最も新しい特目住戸とその上階の一 般住戸の平面図その他を収集した（表一3.1）。

収集は次のとおり行った。

（1）昭和 53 年度以降に建設された特目住戸がない 場合は，それに近い最も新しいものを収集しだ。

（2）昭和 53 年度以降に建設された特目住戸がある 
場合は，建設年度が新しい順に最高 3 プランまで収集し た。

収集できたプランは 169 であったが，一部平家などを 除き, 105 プランを本研究の対象とした。

2) 調查期日

昭和 58 年 7 月, 昭和 59 年 5 月

\section{4. 一般世帯向け住戸の面積水準}

特目住戸は，制度発足以来，身体障害者が居住すると

表一3.1 図面収集の概況（昭和 59 年度）

\begin{tabular}{c|r|r|l|c}
\hline 建設主体 & 配布数 & 回 取 & 回 収 率 & 収集プラン数 \\
\hline 都道府県 & 46 & 38 & 82.6 & 57 \\
\hline 政命指定都市 & 10 & 7 & 70.0 & 17 \\
\hline その他の都市 & 67 & 62 & 92.5 & 95 \\
\hline 計 & 123 & 107 & $87.0 \%$ & 169 \\
\hline
\end{tabular}

表一4.1 一般住戸の住戸面積の経年変化

\begin{tabular}{|c|c|c|c|c|c|}
\hline & \multirow{2}{*}{ ブラン数 } & \multirow{2}{*}{ 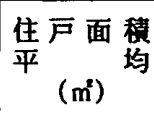 } & \multirow{2}{*}{ 骠準偏差 } & \multicolumn{2}{|c|}{ 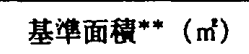 } \\
\hline & & & & 第 2 種 & 第 1 種 \\
\hline 昭和 $48 \sim 51$ 年 & 13 & 48.31 & 6. 52 & 54.2 & 57.5 \\
\hline 昭和52年 & 11 & 56.43 & 9. 52 & 60.7 & 64.0 \\
\hline 昭和53年 & 18 & 56.77 & 3. 59 & 62.7 & 66.0 \\
\hline 昭和54年 & 24 & 57.49 & 4. 83 & 64.7 & 68.0 \\
\hline 昭和55年 & 14 & 58.54 & 5. 62 & 66.7 & 70.0 \\
\hline 昭和56年 & 22 & 60.44 & 4. 10 & 67.7 & 71.0 \\
\hline 昭和57年 & 24 & 59.14 & 3. 53 & 67.7 & 71.0 \\
\hline 昭和58年 & 6 & 61.31 & 4. 01 & 67.7 & 71.0 \\
\hline
\end{tabular}

* : 建設にかかった年度，**: 建設省補助基準面稂 群 : 本対数の一般住戸は第 2 種か $59.2 \%$ 。第 1 程が $40.8 \%$
いうことから，一般住戸と異なる特殊な設計が要求され るとし，それに伴い床面積も一般住戸より広く必要であ るというのが, 一般的な理解であった。ところが, 経年 とともに今日に至り，ノーマリゼーション思想の普及と 相まって，一般住戸の床面積が漸増を重ねた結果 ${ }^{4), 5)}$, 一般住戸の面積水準の下で, 特目住戸の計画が可能であ り，一般住戸にインテグレーションしやすい条件が整っ てきたのではないかという指摘がなされるようになっ た。本研究の発端はここにある。

したがって, 制度発足からしばらくは, 一般住戸の規 模が低水準で同一住戸型では特目住戸について床面積を 一般住戸の $10 \%$ 程度まで割り増しし計画される例が多 かった。そのため上階住戸の 1 階に設置される特目住戸 は，同一住戸型の場合は，南側や妻側に張り出す形態を とる場合が多く, または, 大小住戸の組み合わせとし大 きい方に当てる。そうでなければ，下階特目住戸の住 戸型を上階一般住戸のそれより 1 ランク下げて設 けるというかたちである6)。この両者では, 配置 や構造などの問題を考えた場合, 後者が選択され る例が多くなってきている。また，一般住戸の面 積水準も上昇し, 前者の例も增えつつある。しか しいずれにしても，特目住戸は上階一般住戸の面 積水準と住戸型による平面構成に制約を受けると ころが大きい。

後述のように，特目住戸計画は，一般住戸の平 面構成をベースに計画されているものが大半を占 めている。このような状況から, 特目住戸の計画 条件としては，上階一般住戸の面積水準のレベル アップが重要な鍵である。

そこで, 現在までに供給されている上階一般住 戸がどのような面積水準にあり，その経年変化は

表一5.1 下階特目住戸と一般住戸との住戸型の対応

\begin{tabular}{|c|c|c|c|c|c|c|c|c|c|c|c|c|c|c|c|c|c|c|c|c|c|c|}
\hline & \multicolumn{20}{|c|}{ 下䐕目住戸夕イフ } & \multirow{3}{*}{ 合 斯 } \\
\hline & & \multicolumn{2}{|c|}{$1 \mathrm{DK}$} & \multicolumn{2}{|c|}{$1 \mathrm{LDK}$} & \multicolumn{2}{|c|}{2} & \multicolumn{2}{|c|}{$20 \mathrm{DX}$} & \multicolumn{2}{|c|}{$2 \perp \mathrm{QKK}$} & \multicolumn{2}{|l|}{3} & \multicolumn{2}{|c|}{ BDKK } & \multicolumn{2}{|c|}{$3 \mathrm{LDK}$} & \multicolumn{2}{|r|}{$\mathrm{K}$} & \multicolumn{2}{|c|}{$4 \mathrm{DK}$} & \\
\hline & & & $\mathrm{H}$ & & $\mathrm{H}$ & & $\mathrm{H}$ & & $\mathrm{H}$ & & $\mathrm{H}$ & & $\mathrm{H}$ & & $\mathrm{H}$ & & $\mathrm{H}$ & & $\mathrm{H}$ & & $\mathrm{H}$ & \\
\hline \multirow{2}{*}{ 上 } & $1 \mathrm{DK}$ & & & & & & & & & & & & & & & & & & & & & 0 \\
\hline & $1 \mathrm{LDK}$ & & & & & & & & & & & & & & & & & & & & & 0 \\
\hline \multirow{2}{*}{ 階 } & $2 \mathrm{~K}$ & & & & & & & & & & & & & & & & & & & & & 0 \\
\hline & $2 \mathrm{DK}$ & & & & & & & 3 & 1 & & & & & & 1 & & & & & & & 5 \\
\hline 般 & $2 \mathrm{LDK}$ & & & & & & & & & 3 & 1 & & & & & & & & & & & 4 \\
\hline \multirow{2}{*}{ 戸 } & $3 \mathrm{~K}$ & & & & & 1 & & 5 & & 2 & & 5 & & 3 & & & & & & & 1 & 17 \\
\hline & BDK & & & & & 2 & & 15 & 4 & $4: 4$ & 6 & & & 27 & 10 & & 4 & & & & & 112 \\
\hline \multirow{3}{*}{$\tau$} & $3 \mathrm{LDK}$ & & & & & & & & & 2 & & & & 2 & & 1 & & & & & & 5 \\
\hline & $4 \mathrm{~K}$ & & & & & & & 1 & & & & & & & & & & & & & & 1 \\
\hline & $4 \mathrm{DK}$ & & 2 & & & & & & 1 & & & & & & 2 & & & & & 1 & & 6 \\
\hline \multirow{2}{*}{ 合 } & & 0 & 2 & 0 & 0 & 3 & 0 & 24 & 6 & 51 & 7 & 5 & 0 & 32 & 13 & 1 & 4 & 0 & 0 & 1 & 1 & \multirow{2}{*}{150} \\
\hline & 品 & & 2 & & 0 & & 3 & & & & & & 5 & & 5 & & 5 & & 0 & & 2 & \\
\hline
\end{tabular}


どうであるかを概観する。そこで一般住戸（3 DK）を 建設年度別に分類し，その面積規模を集計したものが表 一4.1である。これによると，一般住戸（3 DK）の住 戸面積の平均值は，全体的にみると増加傾向を示し，対 象のうち最近の 3 か年は 56 年: $60.44 \mathrm{~m}^{2}, 57$ 年 : $59.14 \mathrm{~m}^{2}, 58$ 年: $61.31 \mathrm{~m}^{2}$ となっていて, 約 $60 \mathrm{~m}^{2}$ の水 準に達している。また，住戸面積のばらつきも年々小さ くなってきている。

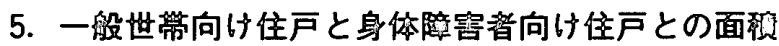 水準の比㩆}

同一住棟内にある下階特目住戸と上階一般 住戸との住戸型の対応を示したものが表一 5.1 である。これによると，特目住戸は DK 型と LDK 型の割合がほぼ同じであるのに対 し，一般住戸は DK 型が $82 \%$ (123/150 例) と割合が高くなっている。一般住戸と比較し て特目住戸に LDK 型が多くみられるのは， LDK 型は車いす使用者にとって移行負担を 軽減できるといった利点があるためである。 次に住戸型でみると，一般住戸では $3 \mathrm{DK}$ が 圧倒的に多く $75 \%$, 特目住戸では $2 \mathrm{DK}$ (30/150 例)， $2 \mathrm{LDK}$ (58/150 例), $3 \mathrm{DK}$ (45/150 例) が多い。住戸型の対応では, 上階一般 $3 \mathrm{DK}$ に対して, 下階特目 $2 \mathrm{DK}$ (19/112 例), $2 \mathrm{LDK}(44 / 112$ 例), $3 \mathrm{DK}$ (37/ 112 例）が主な住戸型の対応である（82％)。 この三つの住戸型の対応を合わせると，全体 の $2 / 3$ を占めている。すなわち，上階一般住 戸と下階特目住戸との連続化を図る場合に は，一般 $3 \mathrm{DK}$ と特目 $2 \mathrm{DK} ， 2 \mathrm{LDK}$, $3 \mathrm{DK}$ との関係が重要になる。そこで，今後 の分析考察の対象を前記の三つの住戸型の対 応に絞ることにする。
住戸規模に関して，一般住戸と特目住戸の連続化の可 能性と限界を探るため, 一般住戸の面積と特目促進会議 案（これまで特目住宅の一つの目安になってきたもの） の特目住戸面積および公室 (K，DK および LDK とす る $)^{7)}$ とサニタリーの最低水準值 ${ }^{8}$ とを比較したものが図 -5.1，図一 5.2 である（なお，ここでは，比較的建設 年度の新しい一般住戸の面積水準を分析の対象とするた め, 全サンプル数 106 から昭和 51 年以前の 5 プランを 除いた 101 プランを抽出する)。
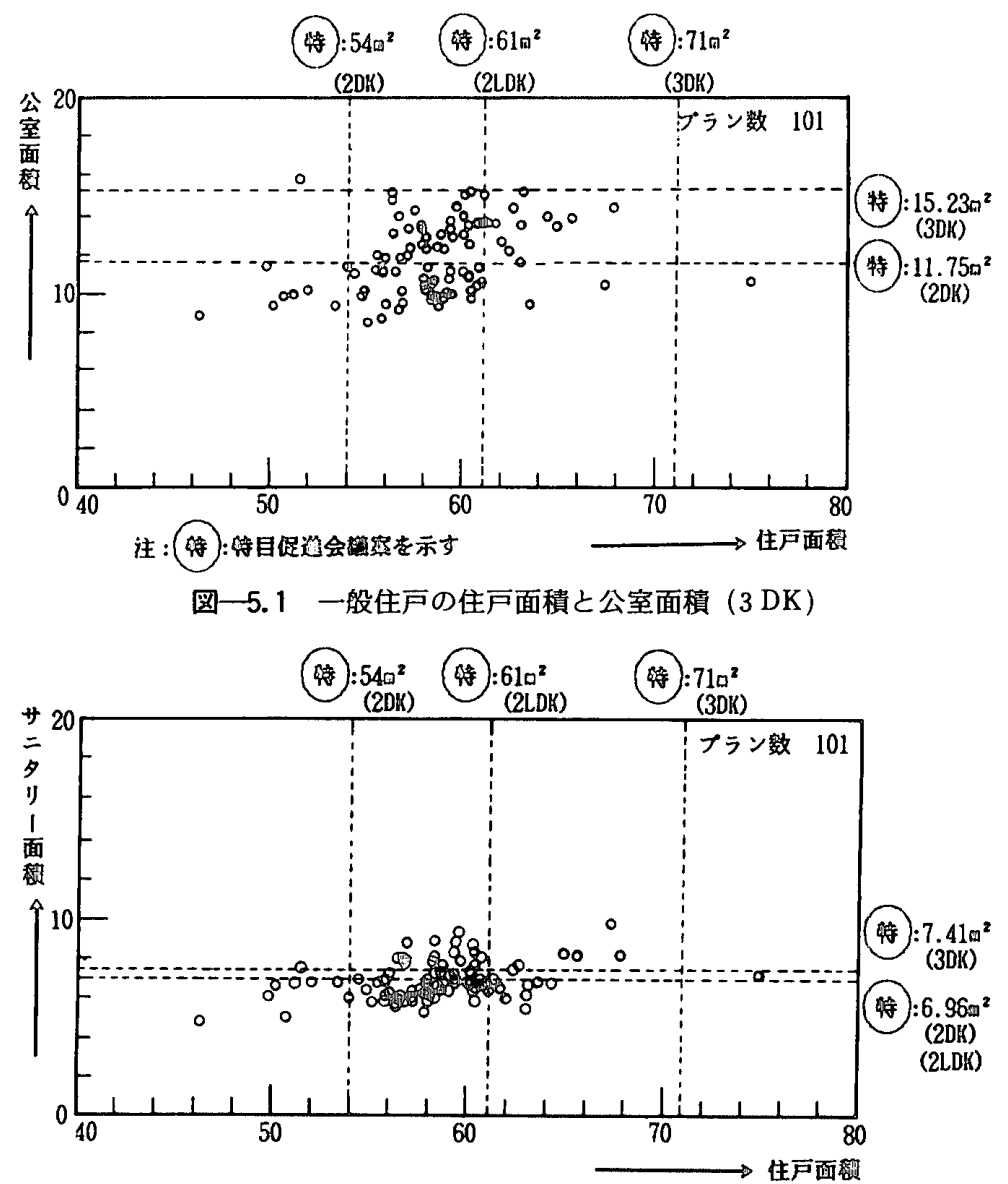

图一5.2 一般住戸の住戸面穦とサニタリ一面積 ( $3 \mathrm{DK})$

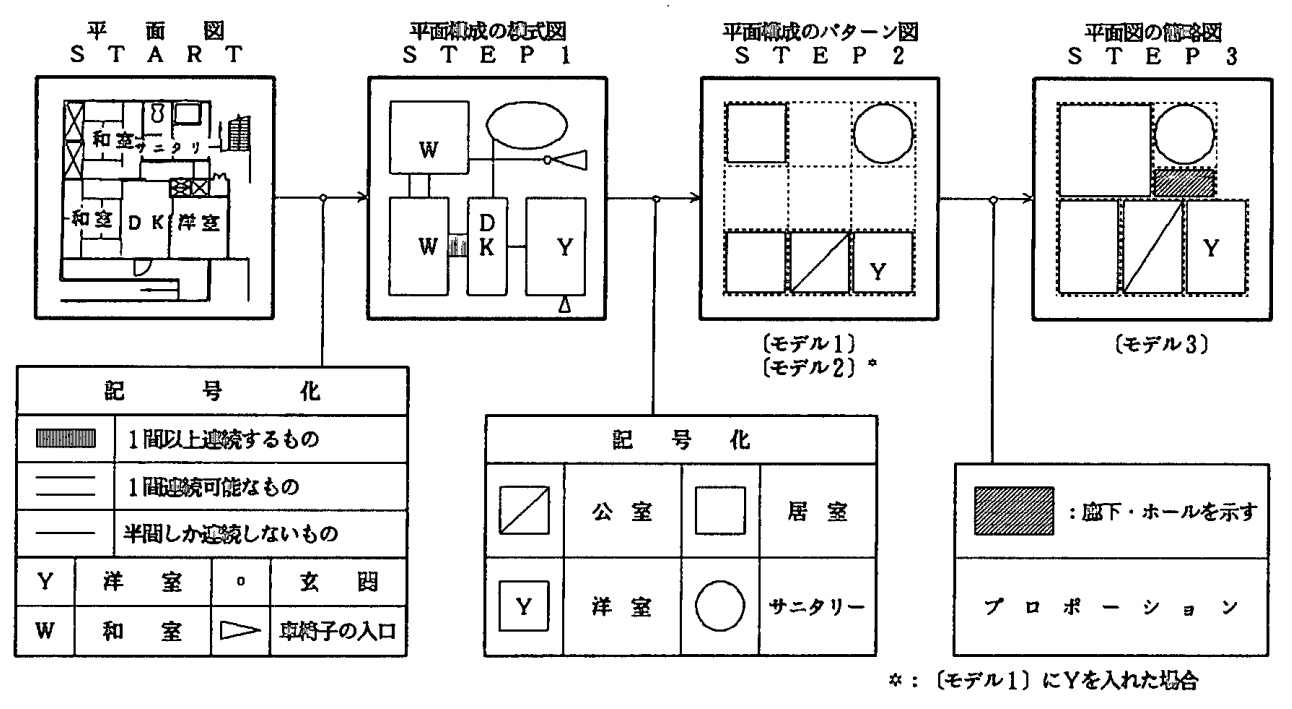

図一6.1 住戸平面穎型化のフローチャート 
（1）住戸面積について

ここでは，上階一般 $3 \mathrm{DK}$ の规模が，下階にくる特目 住戸をどのような住戸型で計画可能にする水準に達して いるのかをみる。その場合に想定する特目住宅の住戸型 の規模は, 特目促進会議の最低水準値（以下, 最低水準 值）以上とする。つまり，一般 $3 \mathrm{DK}$ の規模が，特目の $2 \mathrm{DK} ， 2 \mathrm{LDK} ， 3 \mathrm{DK}$ の各最低水準値をどの程度クリ アするレベルに到達しているかということである。

それによると，全体的には，一般 3 DK の約 $90 \%$ は， 特目 $2 \mathrm{DK}$ の最低水準值 $\left(54 \mathrm{~m}^{2}\right)$ を充たしている。し かし, 特目 $2 \mathrm{LDK}$ の最低水準値 $\left(61 \mathrm{~m}^{2}\right)$ に対しては, 約 $80 \%$ が達していない。また，特目 $3 \mathrm{DK}$ の最低水準 値 $\left(71 \mathrm{~m}^{2}\right)$ を充たしているのはわずか 1 例にすぎない。 ところが, 一般 $3 \mathrm{DK}$ の面積規模は, 先の動向から, (調 查対象のなかで）最新の 58 年度では平均 $61.31 \mathrm{~m}^{2}$ に達 し, $56 \cdot 57 \cdot 58$ 年度でみても平均で約 $60 \mathrm{~m}^{2}$ の水準に 至っていると判断でき，この水準は特目 $2 \mathrm{LDK}$ の最低 水準値に $1 \mathrm{~m}^{2}$ 不足するに過ぎない。

以上から，現状の一般 $3 \mathrm{DK}$ の規模水準では，その下 階に同一規模で特目住戸を計画する場合， $2 \mathrm{DK}$ は十分

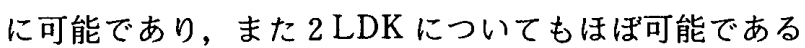
といえる。これに対し，3 DK の規模にはまだ開きがあ り計画は無理である。

（2）公室面積について

公室は，在宅時間が長くなる身体障害者なかでも車い す使用者にとって利用度が高く，その面積は車いす操作 を容易にし可動範囲を広げることから重要である。特目

表一6.1 特目住戸 ( $2 \mathrm{DK}$ ) の平面類型 [モデル 1]・[モデル 2]

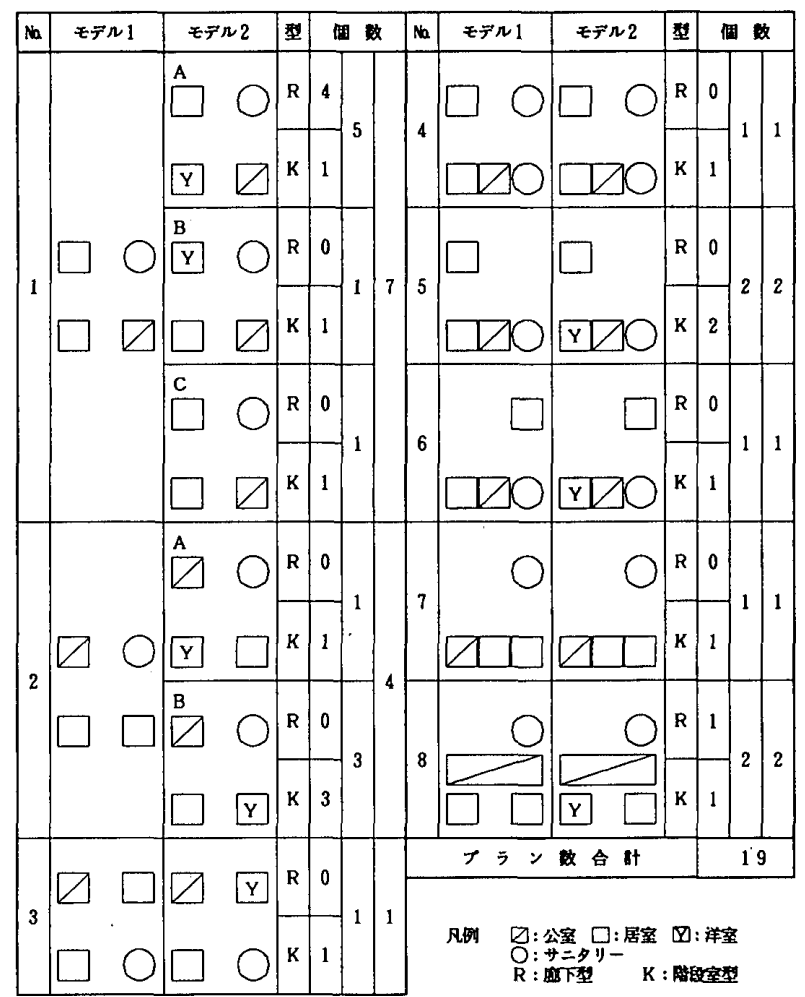

$2 \mathrm{DK}$ の公室面積の最低水準值と比較すると約 $50 \%$ の 一般住戸が最低水準値に達している。3 DK の最低水準 值を充たしているのはわずか 1 例であり，分布としては 水準值をかなり下回っている（図一5.1）。

（3）サニタリー面積について

サニタリーは，身体障害者とくに車いす使用者にとっ ては複雑な動作を求められる室で, 自力で処理または介 助を要する場合いずれもその面積が重要である。サニタ リ一面積の最低水準値と比較すると, 特目 $2 \mathrm{DK}$ および 2 LDK の最低水準值を充たしている一般住戸は約 30 \%であり，3 DK のそれに対しては約 $20 \%$ と低い（図 -5.2)。

なお，一般住戸のサニタリーの面積は，便所・浴室・ 洗面および脱衣スペースを加算したものである。

6. 平面構成の類型化

1）平面類型の方法

同一住棟内における特目住戸と上跸一般住戸の相互関 係を考察するために, 各住戸の平面構成について, 各室 の位置関係，室要素，平面のプロポーションを類型の基

表一6.2 特目住戸 ( $2 \mathrm{LDK})$ の平面類型〔モデル 1)・[モデ ル 2]

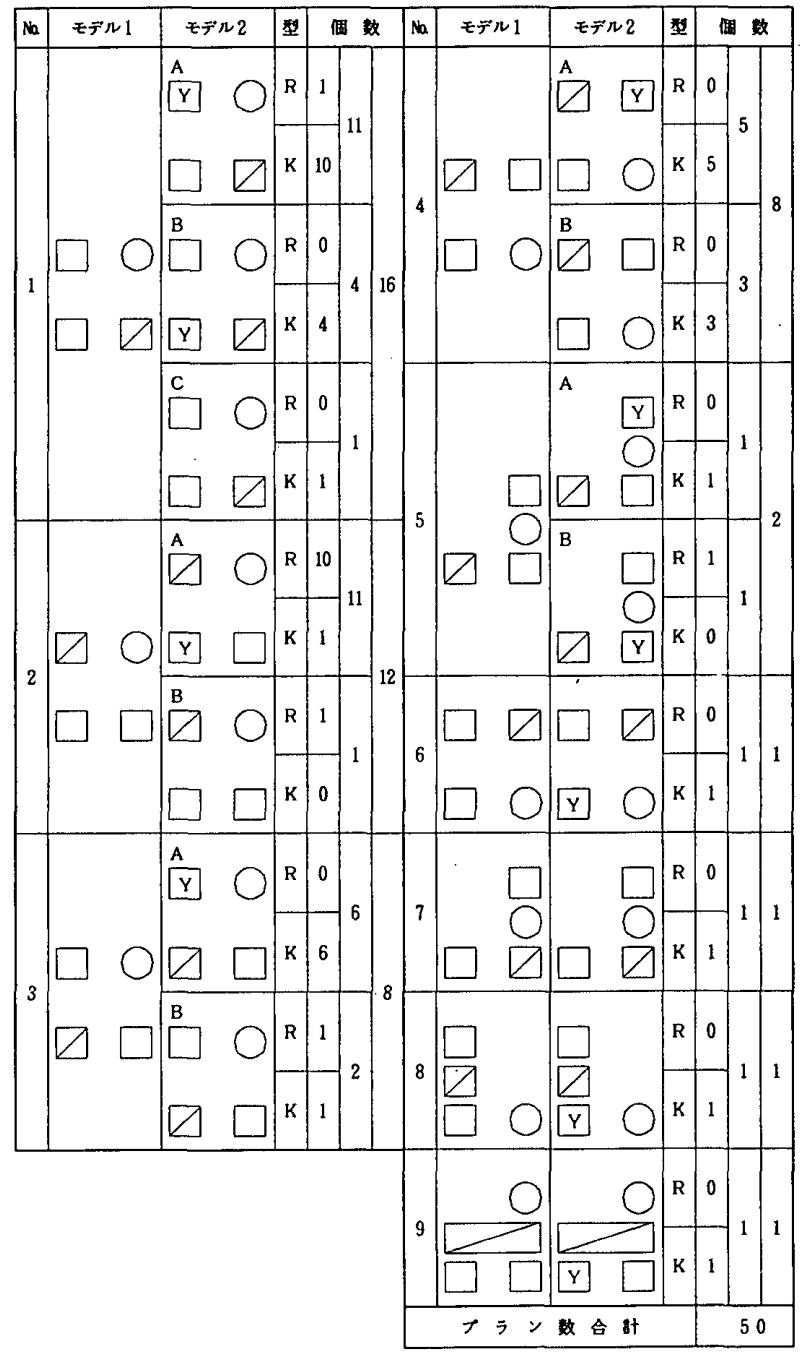


準として平面穎型を行う。室要素は(1)公室, (2)洋室, (3) 居室, (4)サニタリーとし, 各室相互のつながりは考虑し ないものとする。住戸平面の類型化の方法については図 一6.1に示す。

2）身体障害者向け住戸の平面類型からみた特徵

ますこここでは，平面構成の特徵を把握するために，先 の類型方法（図一6.1のSTEP 2) により, 特目 2 DK (19 例), $2 \mathrm{LDK}$ (50 例), $3 \mathrm{DK}$ (37 例) について平 面類型〔モデル 1]・[モデル 2]を行った（表一6.1， 表一6.2，表一6.3(1)，表一6.3(2))。

(1) 特目 $2 \mathrm{DK}$ について (表一6.1)

住戸内における公室の位置は，1例を除き，すべて南 面している $(95 \%)$ 。身体障害者の寝窒となる重要な洋 室は $74 \%$ （14/19 例）が南面している。問題になる洋 室のない住戸が $16 \%$ （3/19 例）ある。

室要素の配置関係による穎型〔モデル 1]（図一6.1 の STEP 2 ) でみると, No.1 (公室一南, サニタリー 一北）が $37 \%$, 次いでNo.2（公室一北，サニタリー 一北）が $21 \%$ と比較的まとまっている。

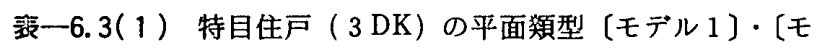
デル 2]

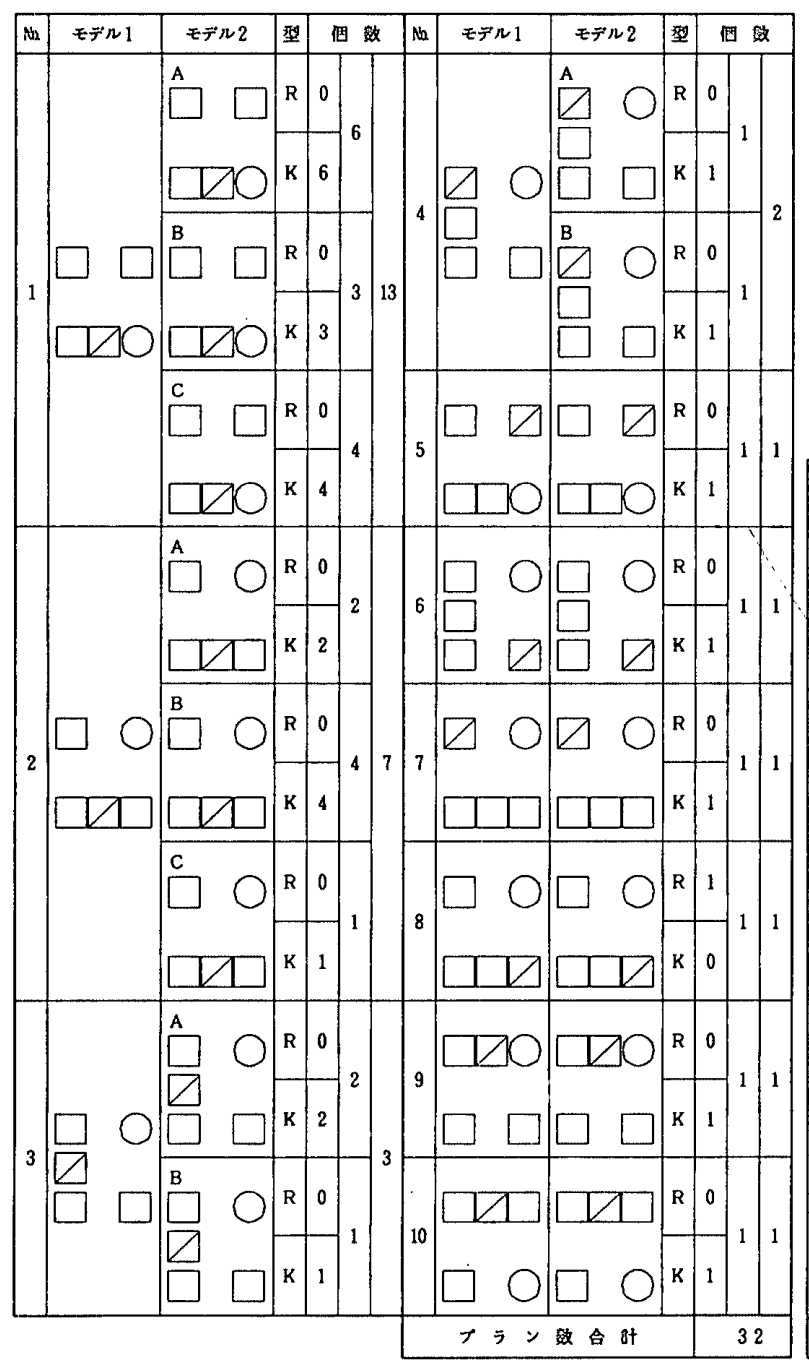

類型〔モデル 2]（図一6.1のSTEP 2 ）によると, 公室と洋室が南面するNo.1-A が主なタイプである (26\%)。

アプローチ形式については, 階段室型が中心である (74\%:14/19 例)。

（2）特目 2 LDK について（表一6.2）

公室の位置が南面しているのは $68 \%(34 / 50$ 例）で ある。洋室の南面している割合は $38 \%$ (19/50 例) と, 2 DKにくらべて低い。洋室のない例は $14 \%$ （7/50 例） である。

䭭型〔モデル 1]でみると, No.1 (公室一南, サニ タリー一北）が $32 \%$ で最も多く, 次いでNo.2（公室 一北, サニタリ--北) $24 \%$, No. 4 (公室一南, サ二 タリー一南) $16 \%$, No. 3 (公室一南, サニタリー一北) $14 \%$ と続き，これら 4 タイプで $86 \%$ を占める。

類型〔モデル 2〕によると, No.1-A (公室一南, サ ニタリー一北, 洋室一北) とNo.2-A (公室一北, サ二 タリー一北, 洋室一南）がともに $22 \%$ でまとまり, 公 室と洋室が南面する条件のよいNo.1-B は1割に満た ない。

主なアプローチ形式は階段室型である $(72 \% ： 36 / 50$

褧一6.3(2) 特目住戸 ( $3 \mathrm{DK}$ ) の平面䫛型 〔モデル1]・\{モデル 2)

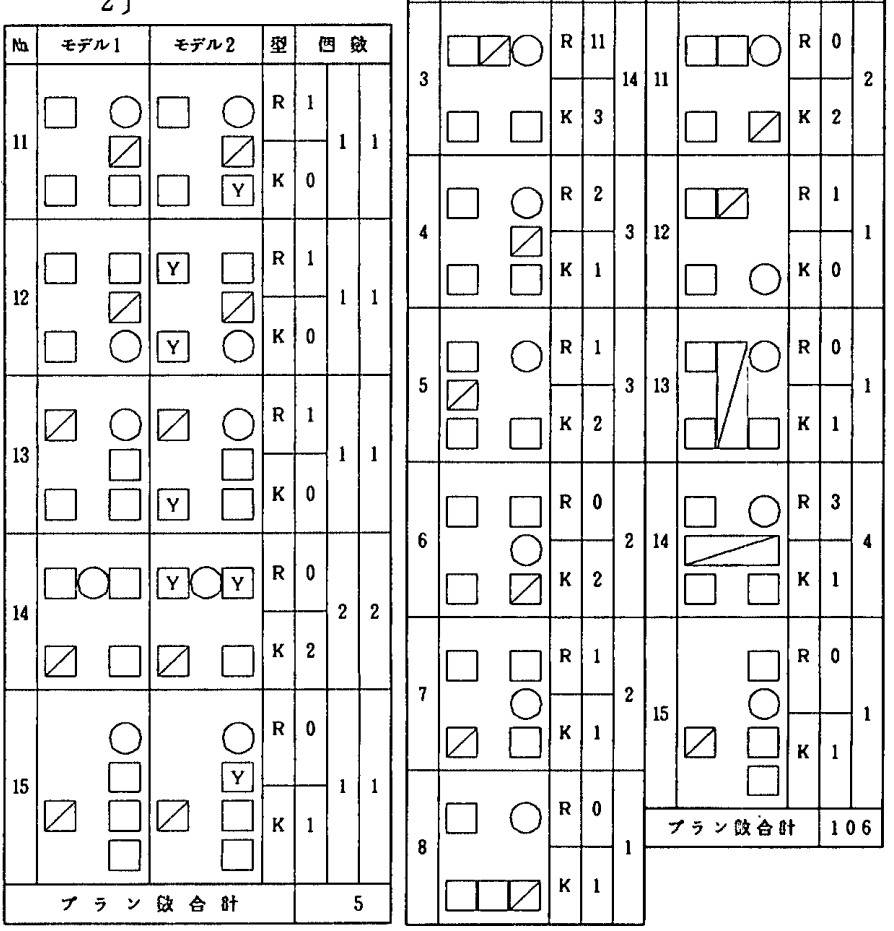


例)。

（3）特目 3 DK について（表一6.3(1)・(2)）

南面している公室は $65 \%$ （24/37 例）である。1 例を 除き洋室を有し設置率が高い $(97 \%)$ 。洋室は約半数

（18/37 例）が南面し， 2 DK と 2 LDK の場合の中間 的な割合になっている。

類型〔モデル 1〕によると, No.1 (公室一南, サ二 タリー一南）が $35 \%$ と多く, 次いでNo.2（公室一南, サニタリー一北）が $19 \%$ である。

類型〔モデル 2〕でみると，まとまっているのは No.1-A（公室一南, サニタリー一南, 洋室一北) の 16 \%にすぎない。公室と洋室が南面するのが 5 タイプ (No.1-B，2-A，2-C，6，8) あるが，それぞれ例数 は少ない。

アプローチ形式では， 90 \% (33/37 例) とほとんどが 階段室型である。

3）一般世帯向け住戸の平面構成からみた特徵

上階一般 $3 \mathrm{DK}$ の 106 例について, 特目住戸と同様の 方法で，平面類型を行った（表一6.4）。これによると， 公室の南面は $78 \%$ (83/106 例), サニタリーの北面は $56 \%$ (59/106 例) である。

類型〔モデル 1〕でみると, No.1 (公室一南, サ二

表一7.1 上階一般住戸と下階特目住戸の[モデル 3] の対応 (3 DK-2 DK)

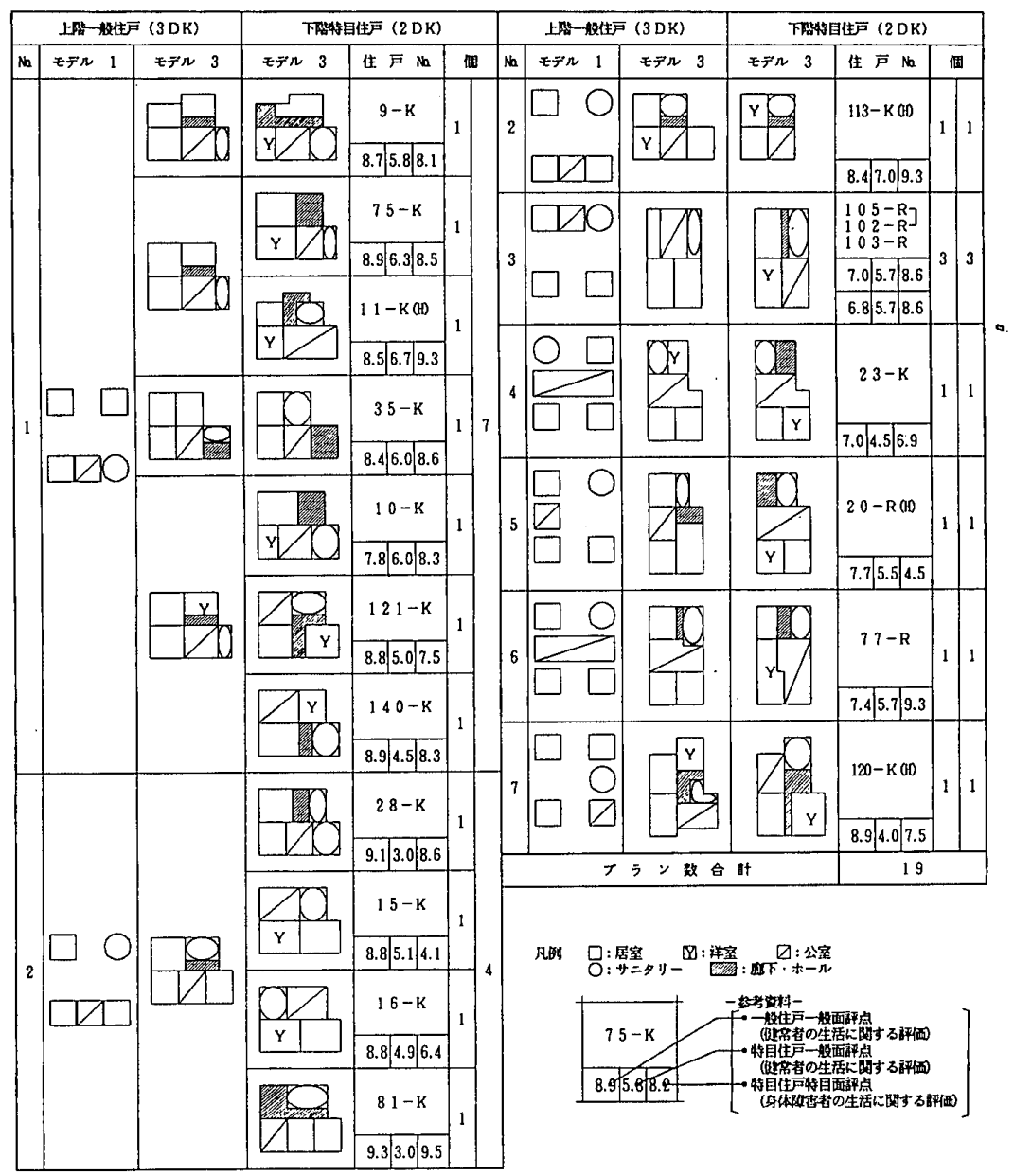

タリー一南・ $38 \%$ ), No. 2(公室一南, サニタリー一北・ $28 \%$ ), No. 3 (公室一北，サニタリー一北・13\%）が 主なタイプである。

アプローチ形式別では，階段室型が 78 \% (83/106 例) を占めている。

7. 下階特目住戸と上階一般住戸との平面構成の関係

1) 平面構成の対応

下階特目住戸と上階一般住戸の平面構成の対応関係を 特目 $2 \mathrm{DK}$ 一一般 $3 \mathrm{DK}$, 特目 $2 \mathrm{LDK}$ 一一般 $3 \mathrm{DK}$, 特目 $3 \mathrm{DK}$ 一一般 $3 \mathrm{DK}$ について考察する。まず, 上記の住 戸型の対応を図一6.1のSTEP 2, STEP 3 を用いて, 住戸型別に平面構成の対応を示したものが表一7.1 表 一7.5 である。さらに上記の表に基づき, 上階一般住戸 ( $3 \mathrm{DK}$ ) からみた下階特目住戸 ( $2 \mathrm{DK}, 2 \mathrm{LDK}, 3 \mathrm{DK}$ ) の平面構成の変化を分類整理するために, 特目住戸の室 要素として重要な意味をもつ公室とサニタリーの位置関 係を分類軸に定めて分類したものが表一7.6である。

上階と下階とで室の「位置の変化」や「ズレ」および 「面積の変化」を判断するため, 表一7.6 の分類軸とし て公室とサ゚ニタリーの項目について，以下のようなレべ ルを設定する。

(1) 縦軸一サニタリーについて

「位置変化なし」：下階特目住戸のサニ タリーの位置が, 上階一般住戸と同一の 場合

「一部ズレ」：下階特目住戸のサニタ リーの位置が, 上階一般住戸の位置と一 部ズレを生じている場合

「移動」：下階特目住戸のサニタリーの 位置と上階一般住戸の位置が全くズレて いる場合

「面積変化小」:下階特目住戸と上階一 般住戸のサニタリーの面積の差が $2 \mathrm{~m}^{2}$ 未満の場合9)

「面積変化大」: 下階特目住戸と上階一 般住戸のサニタリーの面積の差が $2 \mathrm{~m}^{2}$ 以上の場合 ${ }^{10)}$

(2) 横軸一公室について

「公室の変化なし」：上階一般住戸と下 階特目住戸の公室の位置および面積がほ とんど変化のない場合

「その他変化なし」：一般住戸の公室 と特目住戸の公室とが重なりズレの ない場合

『その他変化あり」：一般住戸の公室 と特目住戸の公室とが重なっている が一部ズレがある場合

「隣接居室への公室拡大」：下階特目住 
表一7.2 上階一般住戸と下階特目住戸の〔モデル 3] の対応 (3 DK-2 LDK)

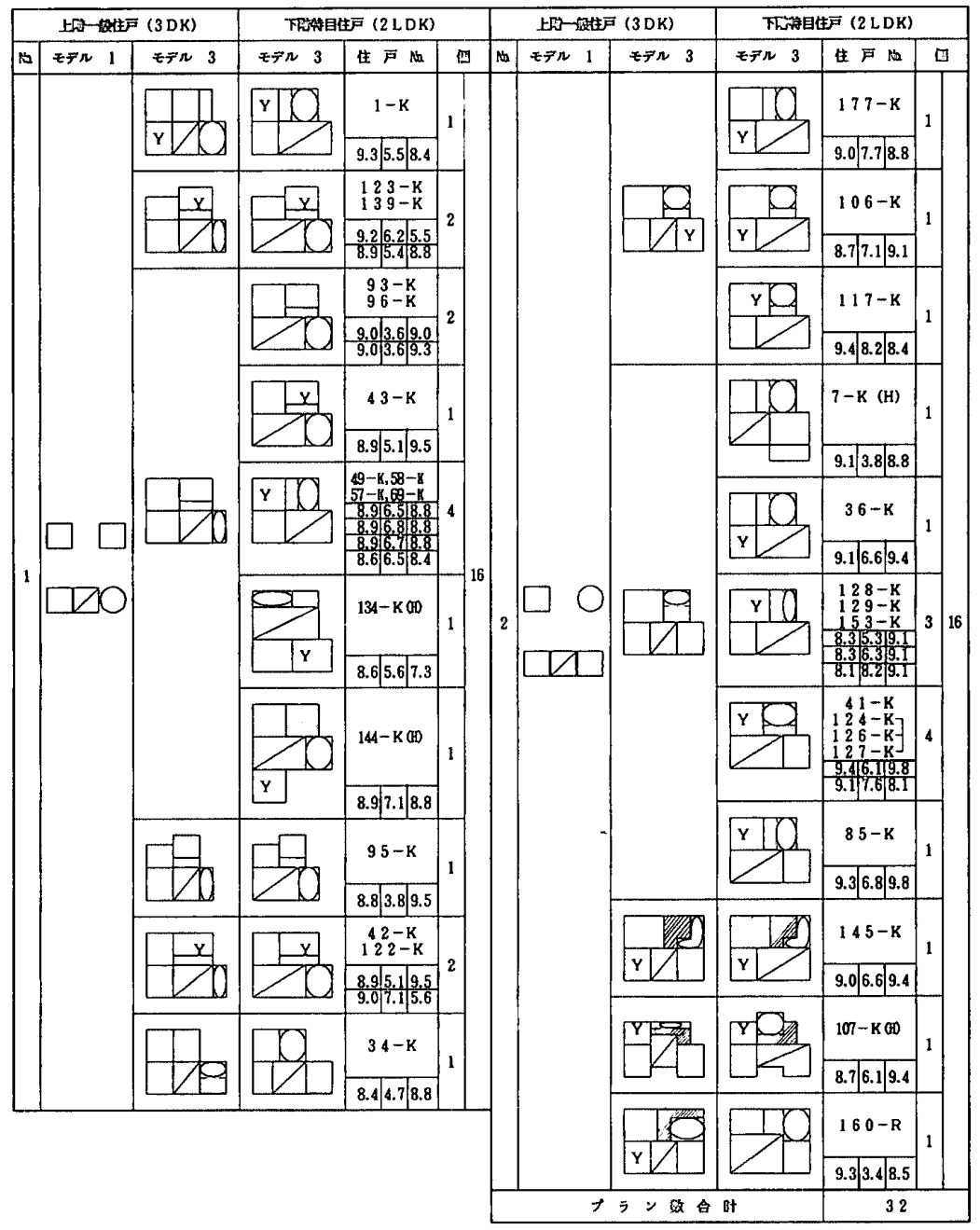

䨿一7.3 上階一般住戸と下階特目住戸の〔モデル 3〕の対応 (3 DK-2 LDK)

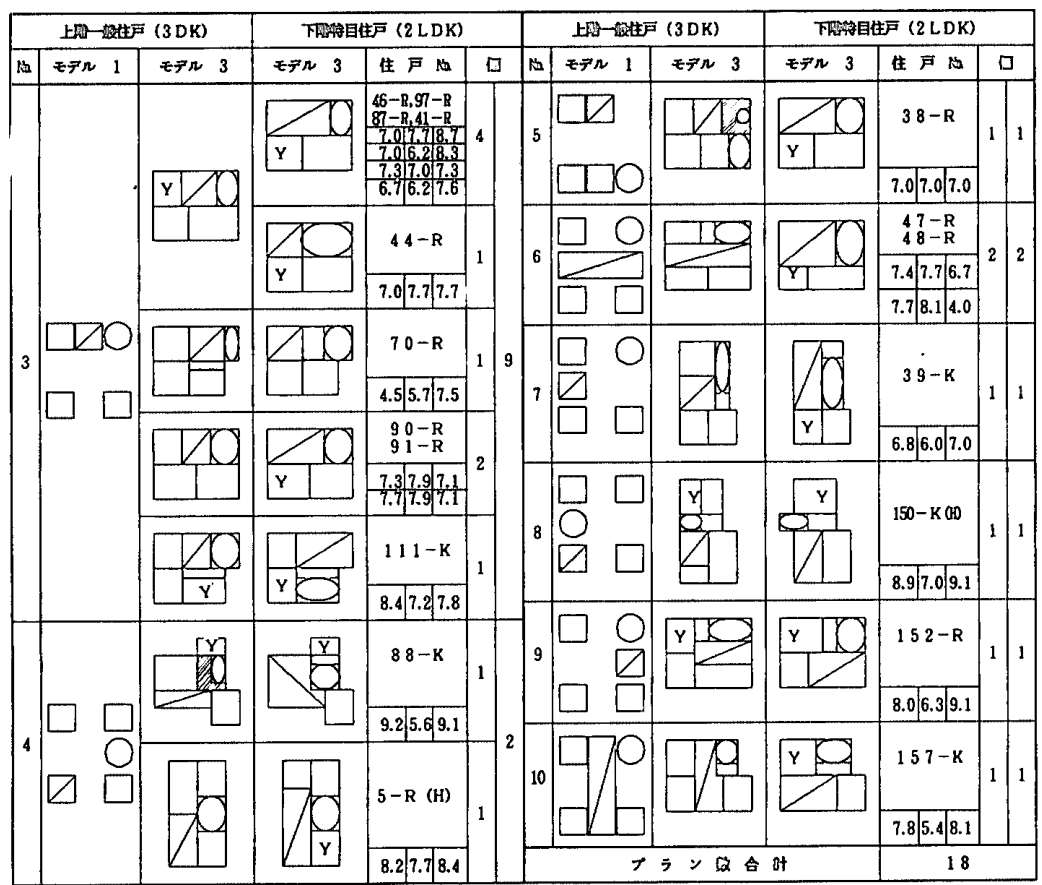

戸の公室が上階一殷住戸の公室とそれに 隣接する居室の 2 室分に相当する場合

「隣接サニタリーへの公室拡大」：下階 特目住戸の公室が上階一般住戸の公室と それに满接するサニタリーの 2 室分に相 当する場合

「公室の移動」：特目住戸と上階一般住 戸の公室の位置がまったく一致しない場 合

（1）特目 $2 \mathrm{DK}$ の場合

上階一般住戸に対し，「公室の移動」 が多いが (53\%：10/19 例), サニタリー については「位置変化なし」が $63 \%$ (13/19 例), 「面積変化小」が $58 \%$ (11/19 例) と多い。傾向としては全体 的に上下階で変化するパターンが多く， 対応関係は弱い。

（2）特目 $2 \mathrm{LDK}$ の場合

2 例を除くと，公室は移動せず㔍接居 室またはサニタリーの方に拡大する変化 パターンがすべてである。なかでも「隣 接居室への公室拡大」の例が多い $(84 \%$ : 42/50 例)。公室の拡大によるサ二夕 リーの位置のズレまたは位置の変化は少 ない。しかし，サ二タリーの「面積変化 大」は $54 \%(27 / 50$ 例) と半数をこえる。 上下階で, 全体的に強い対応関係がみら れる。

\section{（3） 特目 $3 \mathrm{DK}$ の場合}

上下階で同一住戸型であることによ り，最も強い対応関係にある。「公室の 変化なし」が $70 \%$ (26/37 例), サニ夕 リーの「位置変化なし」が $62 \%(23 / 37$ (例), さらに「公室の変化なし」かつサ二 タリーの「位置変化なし」が $54 \%$ (20/37 例) で，公室およびサニタリー の位置に変化のない例が多い。しかし, 「公室の移動」およびサニタリ一の「移動」 もともに約 $1 / 4$ を占める $(24 \%, 27 \%)$ 。

8. 下階特目位戸と上階一般住戸との 平面箱成の共通性

1）共通性の高い平面䭭型の選定基準 先に, 特目住戸と一般住戸の平面構成 の対応関係を考察したが，ここでは，上 階と下階との平面構成において共通性 (変化が少ない)の高いものを選定する。 そのために表一7.6において，下階特目 住戸で身体障害者にとって重要であり， 
表一7.4 上階一般住戸と下階特目住戸の〔モデル 3〕の対応 $(3 \mathrm{DK}-3 \mathrm{DK})$

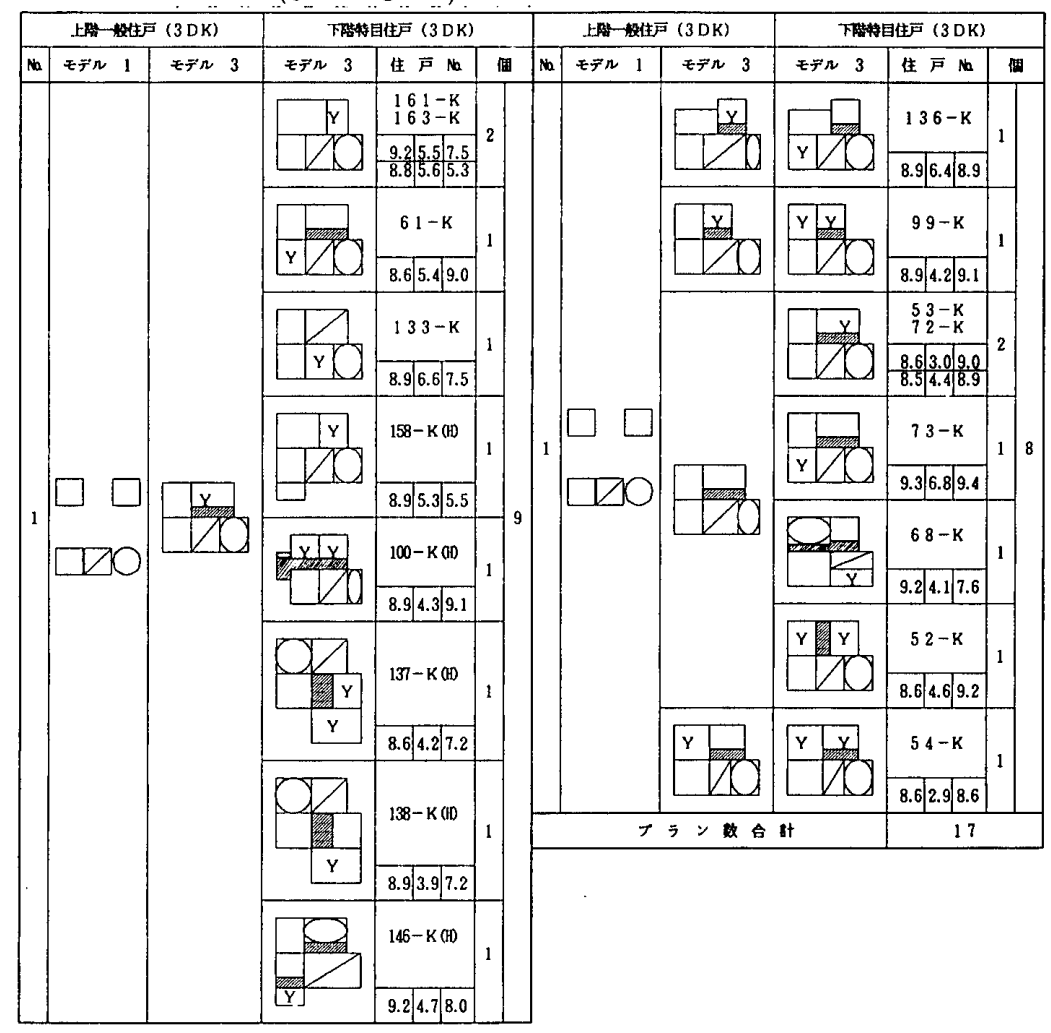

表一7.5 上階一般住戸と下階特目住戸の〔モデル 3〕の対応 (3 DK-3 DK)

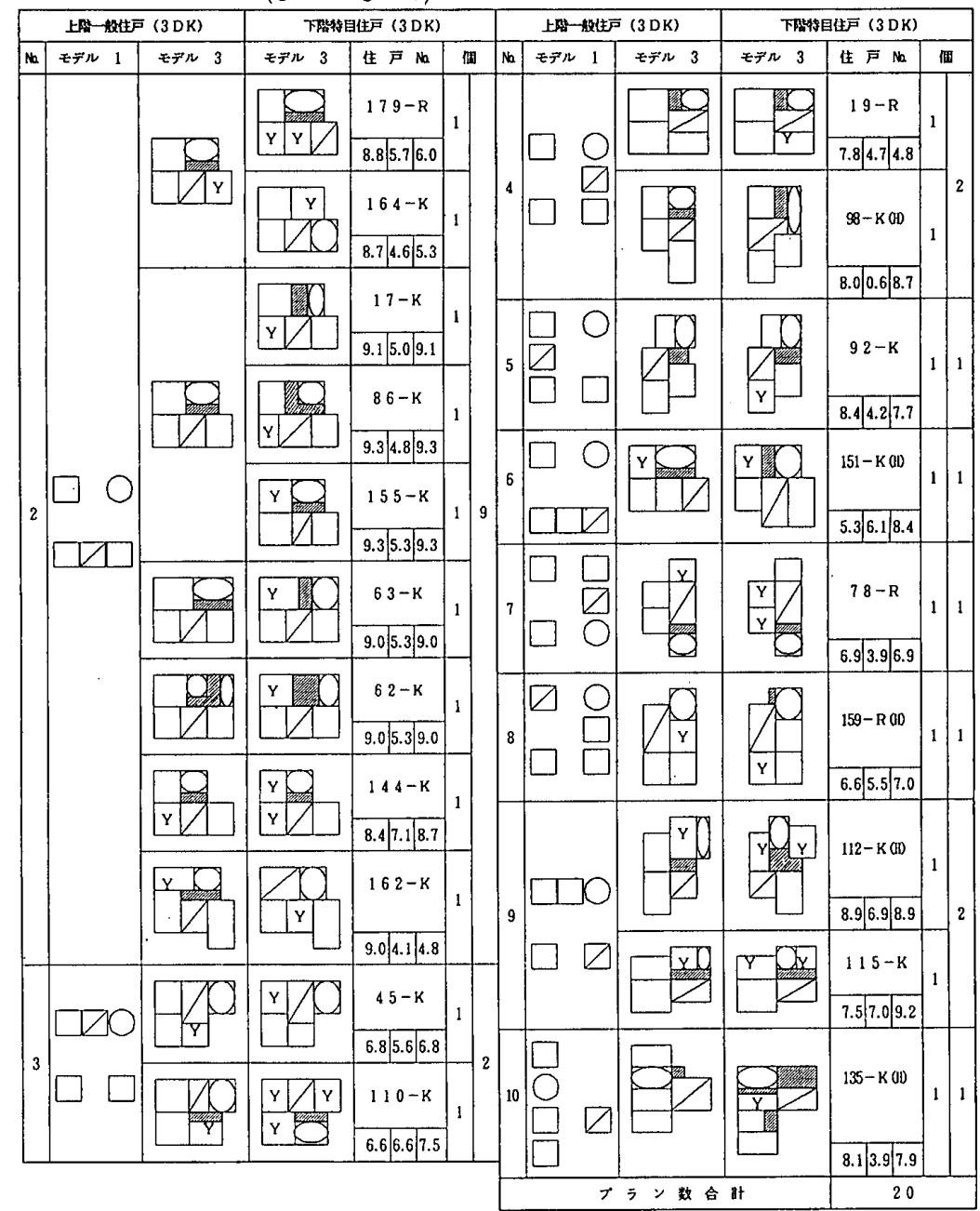

上階一般住戸との間で変化しやすい公室 とサニタリーについてその変化の度合に より選定する基準として，次のように定 めた。

\section{[選定基準］}

(1)「公室変化なし」と「サニタリー 位置変化なし」

(2)「隣接居室への公室拡大」と「サ ニタリ一位置変化なしかつ面積変化小」

(3)「公室変化なし」と「サニタリー の部分的な位置ズレ」

2）共通性の高い平面類型

先の選定基準により, 表一7.6より変 化度の小さい共通性の高い住戸を選定し た（表一7.6のスクリーン部分）。その 結果, 上階一般 $3 \mathrm{DK}$ に対して, 共通性 の高いプランが出現する比率は, 下階特 目 $3 \mathrm{DK}$ が $54 \%$ (20/37 例) で最も高く, $2 \mathrm{LDK}$ と $2 \mathrm{DK}$ とはほぼ同じ值で低い (22\%:11/50 例, $21 \%: 4 / 19$ 例)。

これらの共通性の高いプランについ て，上階に対し同一の区画でなされてい ない「H（張り出し)」のあるものを除 外し，上階一般住戸と下階特目住戸の対 応を〔モデル 3〕で示したものが表一 8. 1, 2, 3 である。

これについて住戸型別にみると, 特目 $2 \mathrm{DK}$ の場合は上階一般 $3 \mathrm{DK} に$ 対し て, 1 居室分面積的な余裕ができるため, それを玄関およびホール部分の拡大をは かっているが，ほかの室の変化はみられ ない。

特目 $2 \mathrm{LDK}$ の場合は，2 $\mathrm{DK}$ と同様 に，1居室分の余裕があるため，上階一 般住戸の公室 DK に隣接する居室へ拡 大し, 公室 LDK を計画している。その 他の変化としては, 洋室のとり方やサ二 タリーのわずかな面積増加がみられる程 度である。

特目 $3 \mathrm{DK}$ の場合は，上階一般住戸と 同一住戸型であるため，全体として平面 構成の共通性が非常に高い。一部に，下 階特目住戸のサニタリーや廊下ホール部 分の拡大に伴い, 上階一般住戸との間で 小さな変化がみられる。

3）平面構成の共通性

これまで下階特目住戸と上階一般住戸 の関係について考察してきたことをまと 
めてみると，以下のようになる。

（1）頑型〔モデル 1]・〔モデル 2]（図一6.1の STEP 2 ) による考察

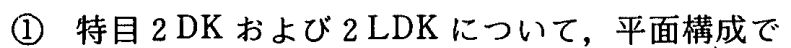
例数が多いのは, No.1 (公室一南, サニタリー一北)
およびNo.2（公室一北，サニタリー一北）であり，公 室のタイプは異なるものの平面構成においては，穎似性 が高い。しかし，特目 $3 \mathrm{DK}$ は， $2 \mathrm{DK}$ および $2 \mathrm{LDK}$ とは居室数が異なることもあって, 穎似性は認め難い。

(2) 特目 $3 \mathrm{DK}$ と一般 $3 \mathrm{DK}$ について平面構成で例数

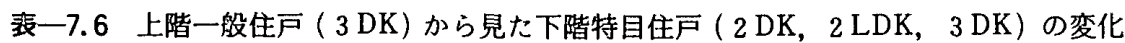

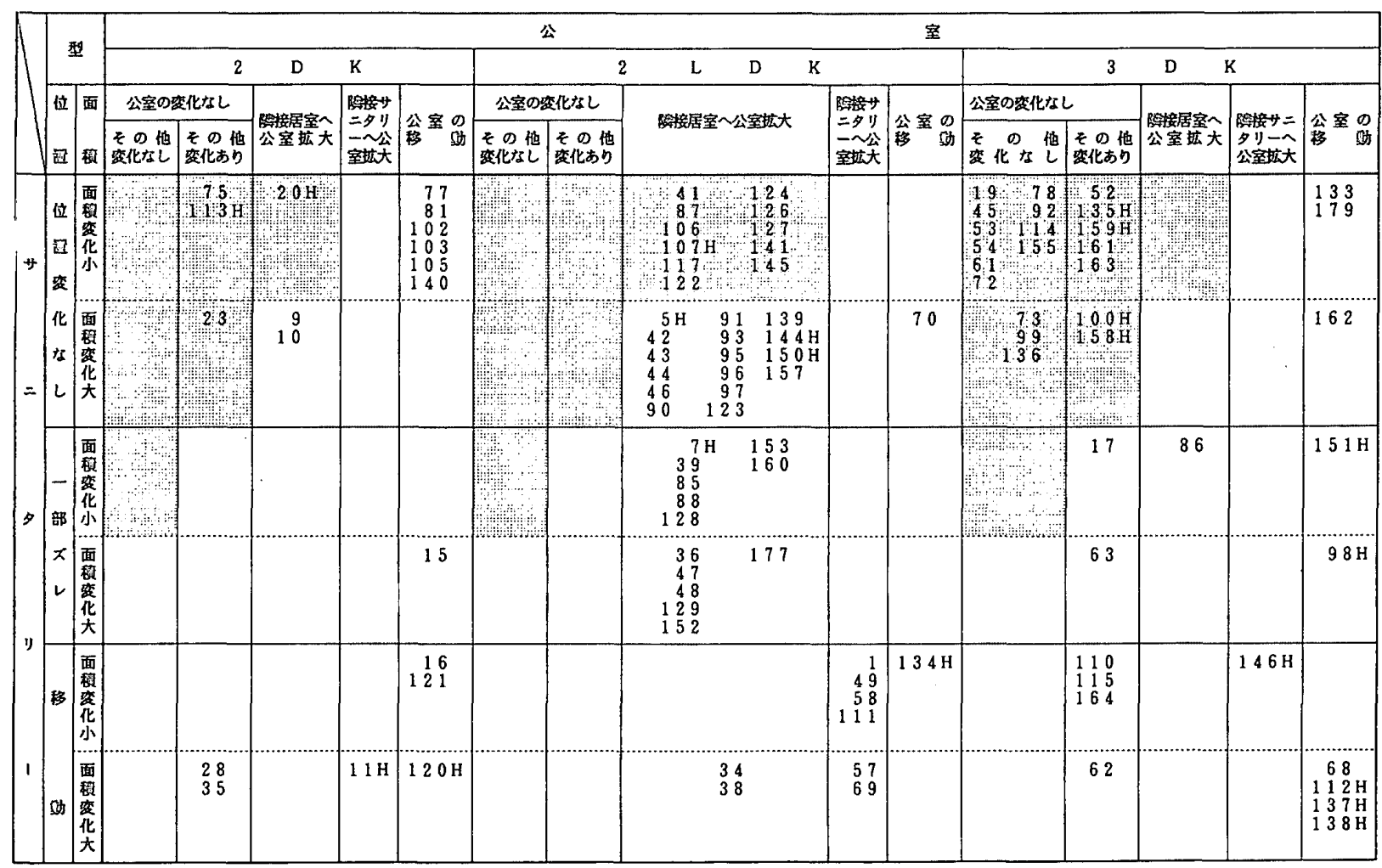

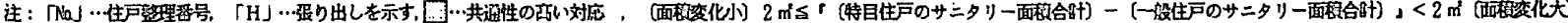

盖一8.1 上階一段住戸と下階 特目住戸の共通性の 高いモデルの対応 $(3 \mathrm{DK}-2 \mathrm{DK})$

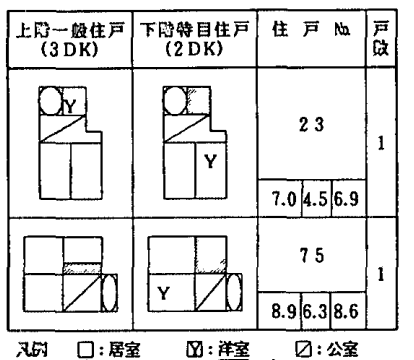

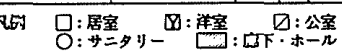

票一8.2 上階一般住戸と下階特 目住戸の共通性の高い モデルの対応 (3 DK2 LDK)

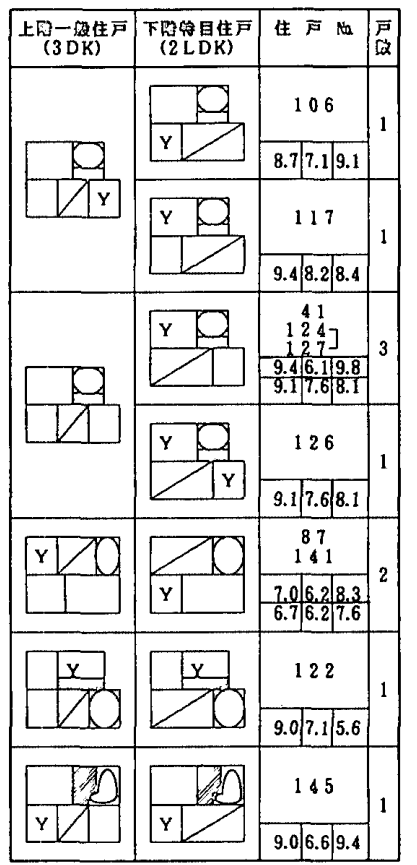

变一8.3 上階一般住戸と下階特目住戸の共通性の高いモデルの 対応 $(3 \mathrm{DK}-3 \mathrm{DK})$

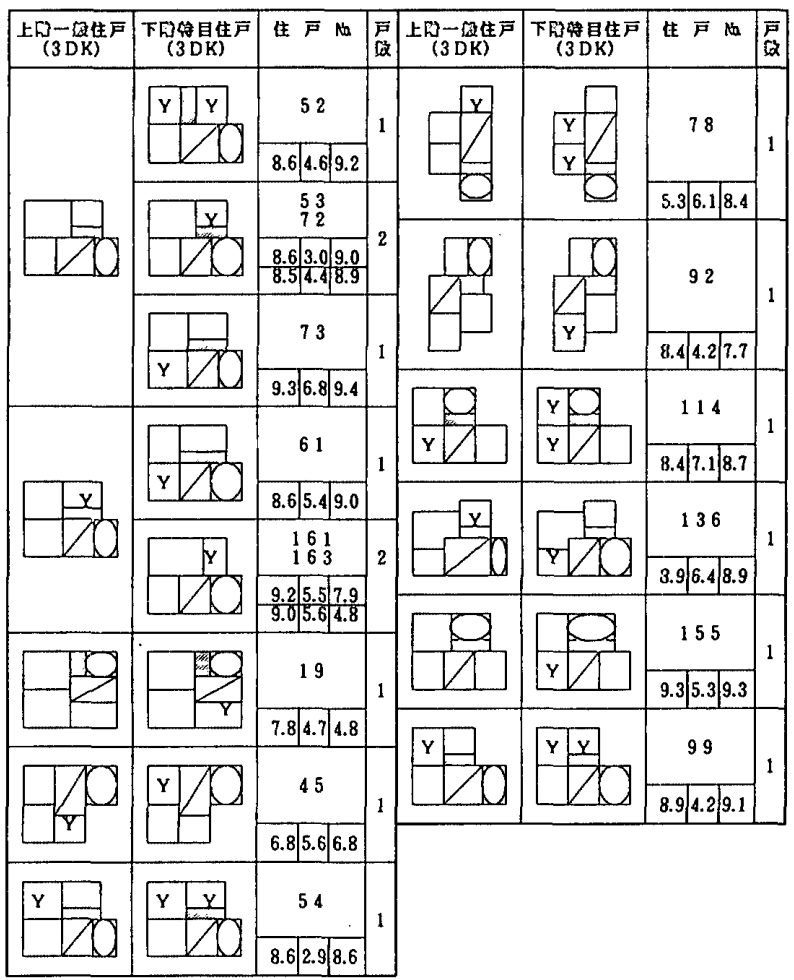


の多いのは, No.1 (公室一南, サニタリー一南)およ びNo.2（公室一南，サニタリー一北）である。住戸型 が同一であることから, 類似性が高い。しかし, 特目 $2 \mathrm{DK}$ および $2 \mathrm{LDK}$ と一般 $3 \mathrm{DK}$ の間には，この類型 モデルの段階ではあまり類似性は認められない。

（2）類型〔モデル 3]（図一6.1のSTEP 3)によ る考察

(1) 上階一般 $3 \mathrm{DK}$ に対して, 平面構成に関して共通 性の高いプランが出現する比率は,「H(張り出し)」を 除くと, (a) 特目 $3 \mathrm{DK}(43 \%)$, (b) $2 \mathrm{LDK}(20 \%)$, (c) $2 \mathrm{DK}(11 \%)$ となっている。

(2)一般 $3 \mathrm{DK}$ に対する下階特目 $2 \mathrm{DK}$ の場合, 公室 の移動する例は多いが, サニタリーの位置は変化しない ものが多い。全体的には変化するパターンが多く, 共通 性は低い。

(3)一般 $3 \mathrm{DK}$ に対する下階特目 $2 \mathrm{LDK}$ の場合, 公 室を隣接居室に拡大するのが変化の基本パターンであ る。つまり,下階特目住戸を計画する際, 上階一般住戸 の公室 DK に隣接する居室を取り込んで公室 LDK とし 計画している。

(4)一般 $3 \mathrm{DK}$ に対する下階特目 $3 \mathrm{DK}$ の場合, 同一 住戸型であるため, 全体としては共通性が高い。

\section{9. まとめ}

（1）現在供給されている住戸型としては，特目住戸 では $2 \mathrm{LDK}$ が中心で, 次いで $3 \mathrm{DK}, 2 \mathrm{DK}$ と 3 タイプ に分かれる。これに対し特目住戸の上階の一般住戸は $3 \mathrm{DK}$ が主である。したがって，下階特目 $2 \mathrm{LDK}$ と上 階一般 $3 \mathrm{DK}$ とが最も主要な対応である。

（2）一般住戸の規模水準は年々上昇し, 本調査の代 表的な一般住戸 $3 \mathrm{DK}$ のうち最新の昭和 $56 \cdot 57 \cdot 58$ 各 年の平均値は $60 \mathrm{~m}^{2}$ に達している。この值は, 特目住戸 の最低居住水準の $2 \mathrm{DK}$ には十分で， $2 \mathrm{LDK}$ には $1 \mathrm{~m}^{2}$ 不足する程度であるが，3DKについては約 $10 \mathrm{~m}^{2}$ 不足 する。その結果, 現在では, 一般住戸 $3 \mathrm{DK}$ (4人 5 人) の規模水準で, 特目 $2 \mathrm{DK}$ および $2 \mathrm{LDK}$ (いずれも 3 人〜 人)については連続化を可能にする設計条件が得 られているといえる。

（3）住戸規模水準の上昇してきた経緯から考察する と, 主たる住戸型であった一般 $3 \mathrm{DK}$ の住戸面積が（建 設五か年計画で)，その最低水準値である $55 \mathrm{~m}^{2}$ 前後の 時期では，それに対応する特目住戸は $2 \mathrm{DK}$ (最低水準 值 $\left.54 \mathrm{~m}^{2}\right)^{11}$ であった。これに対し現在では，一般 $3 \mathrm{DK}$ (4人一 5 人) より下のランクではあるが, 特目 $2 \mathrm{LDK}$ （3人一 4 人）が計画できるようになり，身体障害者向 け特に車いす用に有効な LDK 型が実現可能になったと いう点で意義が認められる。

（4）上階一般住戸と下階特目住戸との平面構成につ いて共通性が高いのは, 上階一般 $3 \mathrm{DK}$ と下階特目
$3 \mathrm{DK}$ の組み合わせであり, 上階一般 $3 \mathrm{DK}$ 上下階特目 2 LDK の組み合わせでは平面類型モデルによる共通性 は低下するが, 対応関係は強い。

（5）しかし, 住戸面積との関係でみると, 上階一般 $3 \mathrm{DK}$ 之下階特目 $3 \mathrm{DK}$ の場合は, 同じ住戸型であり平 面構成が共通しやすい条件を持つからであるが, 面積的 には特目 $3 \mathrm{DK}$ の最低水準値は $71 \mathrm{~m}^{212)}$ であり, 現状で は最低水準値以下で押し込め, 計画されていることにな る。したがって，身体障害者向け特に車いす用として重 要な DK が, 特目 $3 \mathrm{DK}$ では狭小で最低値を下回り, 問 題が多い。これに対し, 上階一般 $3 \mathrm{DK}$ と下階特目 2 LDK の場合は, 両住戸ともほぼ面積的に充足し, 下 階特目住戸の LDK は主として上階一般住戸の DK と隣 接居室を一体化して面積が確保され，問題は少ない。

今後は, 主要な対応である上階一般住戸 $3 \mathrm{DK}$ 上下階 特目住戸 $2 \mathrm{DK}, 2 \mathrm{LDK}, 3 \mathrm{DK}$ の平面のなかから共通 性の高いものについて, 身体障害者の面（特目面）と一 般健常者 (一般面) から評価し, 面積についても検討を 加え, 連続化の可能な特目住戸と一般住戸のモデルプラ ンのベースを選定するつもりである。

\section{謝 辞}

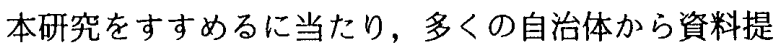
供にご協力を頂いた。研究の過程で村上良知久留米工業 大学助教授より適切な教示を頂いた。また, 元大分大学 院生 - 藤田正文, 技官 - 中武啓至, 大分大学院生 - 中村 禎男, 同 岡本恒之の各氏に多大なご協力を頂いた。記 して感謝の意を表します。

なお, 本研究は文部省科学研究費 (試験)によって行っ た。

\section{註}

1）砂原茂一：リ八ビリテーション, 岩波書店, pp. 186 187, 1980

2）特定目的公営住宅建設促進会議編：老人向け住宅の計 画・身体障害者向け住宅の計画, 日本住宅協会, pp. 386 〜 404, 1974

ここでは, 住宅建設五か年計画において住宅規模の最 低水準および平均水準が提示されているが，それと同様 のものを，身体障害者向け住宅について提示している。

そのために, 本城提案 (一般公営住宅) を参考に，ま ず住宅を構成する室が決められ，次いでそれら各室の規 模について検討提案がなされ，各室の規模を積み上げて 住宅規模を検討提示している。

規模の検討に当たっては, 車いす使用に限定して行わ れている。なお，特に考慮された事項としては，以下の ものがある。(1)家族構成, (2)食寝分離, (3)就寝分離, (4) 公私室の分離, (5)専用室の確保, (6)車い寸通行幅, (7)車 いす回転の場の確保，8車いすで家事作業のスペース確 保。また, 各室の規模については基本的な家具を配置し 検討している。

これについての今後の課題は, 提案の各室のプロポー ションが実施設計の中に旨く納まるかどうか, また実際 
の生活での家具・設備・その他のものを考えるとどうな るか,などを検討し修正していく必要があろう。

3）片岡正喜・村上良知：身障者向特定目的住宅の住戸水準 に関する調查報告 (下)，住宅，1983.7

4）片岡正喜・村上良知：身障者向特定目的住宅の住戸水淮 に関する調㚗報告 (上)，住宅，1983.6

5) 日本建築学会建築計画委員会 ハンディキャップト小委 員会：ハンディキャップ者配感の住宅計画, 彰国社, pp. 33, 1983

6）健康環境システム研究会編：身障者を考えた建築のディ テール，理工図書，pp. 221〜224, 1978

7）「公共住宅設計計画標準について」(建設省住宅局)にい う公室を参考とした。

8）註 2) に同じ。

9）特目住戸と一段住戸のサニタリー面積の差の平均值が $2.09 \mathrm{~m}^{2}$ であったため $2 \mathrm{~m}^{2}$ を採用した。

10)註 9) に同じ。

11) 註 2)に同じ。

12）註 2)に同じ。

\section{SYNOPSIS}

UDC : $725.54: 728.011: 72.011 .2: 333.322 .6$

\section{A STUDY ON CONTINUATY BETWREN A DWELLING-UNIT FOR THE HANDICAPPED AND THAT $\mathbb{F O R}$ THE NON-HANDICAPPED IN THE PUBLIC HOUSE}

Part 1-On the area level of dwelling units and the common features of floor plans-

by Dr. MASAKI IKATAOKA, Prof. of Oita Univ., MAHITO NARAZONO, Assistant of Kyushu Univ., and YUKIO ARITA, Assistant of Oita Univ., Members of A. I. J.

The purpose of this study is to determine whether it is possible to plan public housing with dwelling units common to both the handicapped and non-handicapped.

In the past, there has been a distinction between the dwellings for the handicapped and those for the nonhandicapped. However, since the idea of normalization has become increasingly prevalent, it is now necessary to plan for the handicapped dwellings commensurate with those of the non-handicapped. Facilitating this process, it has become possible to apply the space area level for general housing of the non-handicapped, the most important factor in planning, to dwellings for the handicapped. The area level for general housing, which has been gradually increasing, has reached the point where it seems unnecessary to add additional space to that allotted to the non-handicapped by the level. We gathered from 107 municipal goverments floor plans of dwelling units constructed for the handicapped and non-handicapped after 1978.

The results are as follows:

(1) Of these models, the most common type for the handicapped is 2LDK followed by 3DK and 2DK. For the non-handicapped, 3DK is most common.

(2) The average space area level of $3 \mathrm{DK}$ for the non-handicapped in the last three years is $60 \mathrm{~m}^{2}$ which satisfies the minimum dwelling level of $2 \mathrm{DK}$ currently used for the handicapped, while falling short of the minimum standard for $2 \mathrm{LDK}$ by only $1 \mathrm{~m}^{2}$.

(3) The combination of 3DK for the non-handicapped upstairs and 3DK or 2LDK for the handicapped downstairs results in floor plans compatible for both parties. Some problems occur from the combination of 3DK upstairs and 3DK downstairs. Since the space upstairs determines the space downstairs, individual rooms for the handicapped would be unsuitable. However, if $3 D K$ is upstairs and $2 \mathrm{LDK}$ is downstairs for the handicapped, the DK and adjoining rooms of the upstairs can be combined so that the corresponding space downstairs might be made into a LDK without adversely affecting the dimensions necessary for individual rooms.

(4) Thus, the combination of 3DK for the non-handicapped upstairs and 2LDK for the handicapped downstairs is the most desirable plan. This plan of combination reflects an effort to choose units appropriate for both upstairs and downstairs : the former has been appraised from the perspective of the non-handicapped while the latter has been appraised from the perspective of both the handicapped and non-handicapped. 